\title{
BONEKA JARI SEBAGAI MEDIA PEMBELAJARAN KELAS RENDAH SEKOLAH DASAR
}

\author{
Winda
}

\begin{abstract}
ABSTRAK
Media dalam pembelajaran memiliki peranan yang sangat penting terutama bagi peserta didik dalam hal ini adalah siswa kelas 3 SD, yang mana minat dan motivasi belajar peserta didik dapat ditumbuhkan dengan menggunakan media pembelajaran yang menarik. Selain menumbuhkan minat dan motivasi pada peserta didik, media pembelajaran juga dapat membantu meningkatkan pemahaman, menyajikan data dengan menarik dan terpercaya, merangsang perhatian dan mengaktifkan siswa serta dapat memperjelas penyampaian materi. Adapun manfaat dari penggunaan suatu media pembelajaran akan dapat dirasakan secara optimal apabila guru mampu memilih dan menggunakan media tersebut sesuai dengan tujuan dan fungsinya. Media boneka jari dapat menjadi salah satu alternatif media yang efektif untuk digunakan dalam mengembangkan metode dan meteri pembelajaran yang sesuai dengan tujuan dan fungsi yang ingin dicapai. Dalam hal ini boneka adalah tiruan dari bentuk manusia dan bahkan sekarang termasuk tiruan dari bentuk binatang. Macam -macam boneka untuk media pembelajaran yakni (1). Boneka jari, (2). Boneka tangan, (3). Boneka tongkat, (4). boneka tali, (5). Boneka bayang-bayang. Adapun manfaat boneka jari sebagai media pembelajaran adalah menimbulkan daya tarik siswa, membangkitkan minat bagi siswa untuk belajar, dapat mengembangkan imajinasi siswa, menambah keaktifan siswa dan menambah suasana gembira pada siswa dalam kegiatan pembelajaran.

Kata Kunci: manfaat boneka jari, media pembelajaran, kelas rendah
\end{abstract}

\section{A. Latar Belakang}

Perkembangan Ilmu Pengetahuan dan Teknologi (IPTEK) saat ini ternyata berpengaruh terhadap perkembangan pendidikan di sekolah. Terutama pada penggunaan alat-alat atau media pembelajaran. Seperti yang telah diketahui bahwa dalam paradigma baru pendidikan tidak lagi berpusat pada guru (techer center) melainkan berubah menjadi (student center) atau berpusat pada siswa, meskipun begitu pengelolaan pembelajaran yang baik akan tetap menjadi tugas dan tanggung jawab pengajar yang mana untuk menciptakan pengajaran yang baik tersebut seorang guru harus menerapakan metode pembelajaran yang berdasarkan karakteristik pembelajar. Adapun dalam pengaplikasian suatu metode seorang guru membutuhkan suatu media. Penggunaan media pembelajaran yang tepat dan bervariasi dapat membantu mengatasi sikap pasif peserta didik. Dalam hal ini yakni pengajar ketika memilih media harus terlebih dahulu mengetahui jenis media apa yang sesuai dengan metode pembelajaran, materi dan karakteristik siswanya. Oleh karena itu seorang pengajar perlu mengetahui jenis-jenis media yang dapat digunakan dalam media pembelajaran. Berdasarkan jenisnya media dapat dibedakan

Mahasiswa Prodi Pendidikan Dasar SPS UPI 
menjadi lima, Pertama yakni media pembelajaran berbasis visual yaitu yang hanya mengandalkan indra penglihatan, dengan tujuan ingin menciptakan pembelajaran yang efektif, khususnya untuk pembelajaran dengan tema-tema abstrak. Akan tetapi suatu pengajaran visual akan lebih efektif jika bahan pembelajaran divisualisasikan secara realistik mendekati aslinya. Dalam memilih pembelajaran berbasis visual juga harus memperhatikan 1). Perkembangan usia, 2). Latar belakang budaya siswa, dan 3). Jenis objek yang akan divisualisasikan. Adapun yang termasuk dalam media visual, yaitu (1). Media grafis: gambar atau foto, sketsa, bagan, grafik, papan tulisan, papan flanel, buletin, poster, kartun, dan peta. (2). Media cetak : OHT/OHP, modul. Kedua yakni media pembelajaran berbasis audio dan audio visual. (1). Media audio,yaitu media yang hanya mengandalkan kemampuan suara saja, dalam hal ini berupa, rekaman, dan radio. (2). Media audio visual, yaitu media yang mempunyai unsur suara dan unsur gambar dalam hal ini berupa, televisi, film/video. Ketiga yakni media pembelajaran berbasis lingkungan, dalam hal ini terjadi ketika guru ingin menghadapkan siswa pada keadaan sebenarnya/aktual. Keempat media pembelajaran berbasis komputer. Dalam hal ini digunakan untuk menyampaikan informasi berbasis multimedia. Kelima yakni multimedia dalam pembelajaran, adapun yang dimaksud multimedia yaitu perpaduan antara berbagai media berupa teks, gambar, grafik, sound, animasi, video dan lain-lain yang dikemas dengan menggunakan file digital. Dengan tujuan untuk mengembangkan proses belajar kearah yang lebih dinamis. Adapun sebelum seorang pendidik memilih jenis media yang tepat, seorang pendidik perlu memperhatikan beberapa prinsip pemilihan media pendidikan seperti (1). Tujuan, (2). Ketepatgunaan, (3). Keadaan siswa, (4). Ketersediaan, (5). Mutu teknis. 6). Biaya. Berdasarkan uraian beberapa kriteria pemilihan media di atas dapat diketahui bahwa dalam memilih suatu media harus memperhatikan kesesuaiannya dengan tujuan yang ingin dicapai, ketepatannya dalam mendukung isi pelajaran, media bersifat mudah diperoleh dan praktis, media hendaknya sesuai dengan taraf berpikir siswa dan yang terpenting ialah kemampuan guru dalam menggunakan media yang akan dipilih. Misalnya yakni penggunaan boneka jari sebagai media dalam pembelajaran, maka guru harus dapat menyesuaikannya dengan pembelajaran yang tepat agar proses pembelajaran itu berjalan efektif, yang mana siswa menjadi aktif dan kreatif dan tujuan pembelajaran yang diinginkan dapat tercapai.

Media boneka jari dapat menjadi salah satu alternatif media yang efektif untuk digunakan dalam mengembangkan metode dan meteri pembelajaran yang sesuai dengan tujuan dan fungsi yang ingin dicapai. Dalam hal ini boneka adalah tiruan dari bentuk manusia dan bahkan sekarang termasuk tiruan dari bentuk binatang. Atau dapat dikatakan sebagai salah satu model perbandingan. Boneka dalam penampilannya memiliki karakteristik khusus, maka dalam bahasan ini dibicarakan tersendiri. Macam -macam boneka untuk media pembelajaran yakni (1). Boneka jari, (2). Boneka tangan, (3). Boneka tongkat, (4). boneka tali, (5). Boneka bayang-bayang. Sehingga dapat diketahui bahwa boneka jari bisa digunakan sebagai media pembelajaran. Adapun yang dimaksud boneka jari adalah sebuah boneka yang dibuat dengan alat sederhana, baik itu dari tutup botol, bola pingpong, 
bambu kecil yang dapat dipakai sebagai kepala boneka. Sesuai dengan namanya boneka ini dimainkan dengan menggunakan jari tangan. Kepala boneka diletakkan pada ujung jari atau dalam jari. Dapat juga dibuat dari semacam sarung tangan, atau dari kain flanel, dimana pada ujung jari sarung tangan tersebut sudah berbentuk kepala boneka dan dengan demikian penggunaanya tinggal memainkannya saja. Boneka jari sangat sesuai untuk digunakan sebagai alat permainan yang mendidik, dibandingkan dengan jenis boneka lain, boneka jari lebih mudah digerakan sesuai dengan jalan cerita. Media ini juga memiliki beberapa fungsi, (1). Memberikan pengalaman yang konkret, (2). Memungkinkan siswa menganalisis secara mendalam, (3). Membangkitkan motivasi dan rasa ingin tahu. (4). Informasi yang akan diperoleh akan lebih jelas. (5). Mendorong timbulnya kreativitas. Selain itu boneka jari juga dapat digunakan untuk mengembangkan perbendaharaan kata, melatih diri untuk mendengarkan dan berbicara. Adapun penggunaan boneka jari, yang mana boneka biasanya memiliki kedekatan dengan anak-anak, sehingga kedekatan antar boneka dan anak-anak juga bisa memberikan manfaat sebagai motivasi dari sisi minat peserta didik yang diharapakan dapat mengoptimalkan hasil belajar. Penggunaan media boneka jari ini juga sangat memungkinkan siswa untuk menguasai konsep-konsep yang sedang diajarkan karena siswa turut serta dalam situasi yang sesungguhnya. Media boneka jari ini sangat efektif untuk menarik perhatian siswa dengan bantuan gerakan, ekspresi, dan intonasi.

\section{B. Pembahasan}

\section{Pengertian Media Pembelajaran}

Media sendiri berasal dari bahasa latin (medium) yaitu perantara atau pengantar. Adapun media pembelajaran yaitu sarana atau alat yang dapat digunakan untuk menyalurkan pesan-pesan pembelajaran dari pengajar kepada pembelajarnya, sehingga dapat merangsang pikiran, perasaan, perhatian, minat, dan kemauan pembelajar sedemikian rupa, sehingga proses pembelajaran berjalan efektif sesuai dengan tujuan pembelajaran yang akan dicapai. Media pembelajaran secara umum adalah alat bantu proses belajar mengajar. Segala sesuatu yang dapat dipergunakan untuk merangsang pikiran, perasaan, perhatian dan kemampuan atau ketrampilan pebelajar sehingga dapat mendorong terjadinya proses belajar. Batasan ini cukup luas dan mendalam mencakup pengertian sumber, lingkungan, manusia dan metode yang dimanfaatkan untuk tujuan pembelajaran / pelatihan.

Sedangkan menurut Briggs (1977) media pembelajaran adalah sarana fisik untuk menyampaikan isi/materi pembelajaran seperti : buku, film, video dan sebagainya. Kemudian menurut National Education Associaton (1969) mengungkapkan bahwa media pembelajaran adalah sarana komunikasi dalam bentuk cetak maupun pandangdengar, termasuk teknologi perangkat keras.

Oleh karena proses pembelajaran merupakan proses komunikasi dan berlangsung dalam suatu sistem, maka media pembelajaran menempati posisi yang cukup penting sebagai salah satu komponen sistem pembelajaran. Tanpa media, komunikasi tidak akan terjadi dan proses pembelajaran sebagai proses komunikasi juga tidak akan bisa berlangsung secara optimal. Media pembelajaran adalah komponen integral dari sistem pembelajaran 
Dari pendapat di atas disimpulkan bahwa media pembelajaran adalah segala sesuatu yang dapat menyalurkan pesan, dapat merangsang fikiran, perasaan, dan kemauan peserta didik sehingga dapat mendorong terciptanya proses belajar pada diri peserta didik

Pada hakikatnya bukan media pembelajaran itu sendiri yang menentukan hasil belajar. Ternyata keberhasilan menggunakan media pembelajaran dalam proses pembelajaran untuk meningkatkan hasil belajar tergantung pada (1) isi pesan, (2) cara menjelaskan pesan, dan (3) karakteristik penerima pesan. Dengan demikian dalam memilih dan menggunakan media, perlu diperhatikan ketiga faktor tersebut. Apabila ketiga faktor tersebut mampu disampaikan dalam media pembelajaran tentunya akan memberikan hasil yang maksimal.

\section{Tujuan Menggunakan Media Pembelajaran}

Ada beberapa tujuan menggunakan media pembelajaran, diantaranya yaitu :

a. mempermudah proses belajar-mengajar

b. meningkatkan efisiensi belajar-mengajar

c. menjaga relevansi dengan tujuan belajar

d. membantu konsentrasi mahasiswa

e. Menurut Gagne : Komponen sumber belajar yang dapat merangsang siswa untuk belajar

f. Menurut Briggs : Wahana fisik yang mengandung materi instruksional

g. Menurut Schramm : Teknologi pembawa informasi atau pesan instruksional

h. Menurut Y. Miarso : Segala sesuatu yang dapat merangsang proses belajar siswa

Tidak diragukan lagi bahwa semua media itu perlu dalam pembelajaran. Kalau sampai hari ini masih ada guru yang belum menggunakan media, itu hanya perlu satu hal yaitu perubahan sikap. Dalam memilih media pembelajaran, perlu disesuaikan dengan kebutuhan, situasi dan kondisi masing-masing. Dengan perkataan lain, media yang terbaik adalah media yang ada. Terserah kepada guru bagaimana ia dapat mengembangkannya secara tepat dilihat dari isi, penjelasan pesan dan karakteristik siswa untuk menentukan media pembelajaran tersebut.

\section{Media Boneka Jari}

Boneka adalah tiruan dari bentuk manusia dan bahkan sekarang termasuk tiruan dari bentuk binatang. Jadi sebenarnya boneka merupakan salah satu model perbandingan juga. Sekalipun demikian, karena boneka dalam penampilannya memiliki karakteristik khusus, maka dalam bahasan ini dibicarakan tersendiri. Dalam penggunaan boneka dimanfaatkan sebagai media pembelajaran dengan cara dimainkan dalam sandiwara boneka.

Boneka merupakan model dari manusia, atau yang menyerupai manusia (contohnya Bert), atau hewan. Seringkali boneka dimaksudkan untuk dekorasi atau koleksi untuk anak yang sudah besar atau orang dewasa, namun kebanyakan boneka ditujukan sebagai mainan untuk anak-anak, terutama anak perempuan. Sejak tahun 1940-an pemakaian boneka ebagai media pendidikan menjadi populer dan banyak digunakan di Sekolah Dasar dan Sekolah Lanjutan di Amerika. Di Eropa seni 
pembuatan boneka telah sangat tua dan sangat populer serta lebih tinggi tingkat keahliannya dibandingkan di Amerika.

Di Indonesia penggunaan boneka sebagai media pendidikan massa bukan merupakan sesuatu yang asing. Di Jawa Barat dikenal boneka tongkat yang disebut "Wayang Golek" dipakai untuk memainkan cerita-cerita Mahabarata dan Ramayana. Di Jawa Timur dan di Jawa Tengah dibuat pula boneka tongkat dalam dua dimensi yang dibuat dari kayu dan disebut dengan nama "Wayang Krucil”. Di Jawa Tengah dan di Jawa Timur pula dikenal dengan boneka bayang-bayang yang disebut "Wayang Kulit".

Untuk keperluan sekolah dapat dibuat boneka yang disesuaikan dengan ceritacerita jaman sekarang. Untuk tiap daerah pembuatan boneka ini disesuaikan dengan keadaan daerah masing-masing.

\section{a. Macam-Macam Boneka}

Dilihat dari bentuk dan cara memainkannya dikenal beberapa jenis boneka, antara lain:

1) Boneka jari

Boneka ini dibuat dengan alat sederhana seperti tutup botol, bola pingpong, bambu kecil yang dapat dipakai sebagai kepala boneka. Sesuai dengan namanya boneka ini dima-inkan dengan menggunakan jari tangan. Kepala boneka diletakkan pada ujung jari kita/ dalam. Dapat juga dibuat dari semacam sarung tangan, dimana pada ujung jari sarung ta-ngan tersebut sudah berbentuk kepala boneka dan dengan demikian kita/ dalam tinggal memainkannya saja.

\section{2) Boneka Tangan}

Kalau boneka dari setiap ujung jari kita dapat memainkan satu tokoh, lain halnya dengan boneka tangan. Pada boneka tangan ini satu tangan kita hanya dapat memainkan satu boneka. Disebut boneka tangan, karena boneka ini hanya terdiri dari kepala dan dua tangan saja, sedangkan bagian badan dan kakinya hanya merupakan baju yang akan menutup lengan orang yang memainkannya disamping cara memainkannya juga hanya memakai tangan (tanpa menggunakan alat bantu yang lain).

Cara memainkanya adalah jari telunjuk untuk memainkan atau menggerakkan kepala, ibu jari, dan jari tangan untuk menggerakkan tangan. Di Indonesia penggunaan boneka tangan sebagai media pendidikan/ pembelajaran di sekolahsekolah sudah dilak-sanakan, bahkan dipakai diluar sekolah yaitu pada siaran TVRI dengan film seri boneka "Si Unyil"

\section{3) Boneka Tongkat}

Disebut boneka tongkat karena cara memainkannya dengan menggunakan tongkat. Tongkat-tongkat ini dihubungkan dengan tangan dan tubuh boneka. Wayang Golek di Jawa Barat misalnya adalah termasuk boneka jenis ini. Untuk keperluan penggunaan boneka tongkat sebagai media pendidikan/ pembelajaran di sekolah, maka tokoh-tokohnya dibuat sesuai dengan keadaan sekarang. Misalnya 
dibuat tokoh tentara, pedagang, lurah, nelayan dan sebagainya Boneka tongkat dapat dibuat darikayu yang lunak seperti kayu kemiri, randu, dan sebagainya.

\section{4) Boneka Tali}

Boneka tali atau "Marionet" banyak dipakai dinegara barat. Perbedaan yang menyolok antara boneka tali dengan boneka yang lain adalah, boneka tali bagian kepala, tangan, dan kaki dapat digerak-gerakkan menurut kehendak kita/dalangnya. Cara meng-gerakkannya dengan tali. Dengan demikian maka kedudukan tangan orang yang memain-kannya berada di atas boneka yang dimainkannya. Untuk memainkan boneka tali diperlukan latihan-latihan yang teratur, sebab memainkan boneka tali ini memerlukan keterampilan yang lebih sulit dibandingkan dengan memainkan boneka-boneka yang lainnya. Adakan tetapi memiliki kelebihan lebih hidup dari pada boneka yang lain, karena mendekati gerak manusia atau tokoh yang sebenarnya.

5) Boneka Bayang-bayang

Boneka bayang-bayang (Sadhow Puppet) adalah jenis boneka yang cara memainkannya dengan mempertontonkan gerak bayang-bayang dari boneka tersebut. Di Indonesia khususnya di Jawa dikenal dengan "Wayang kulit". Namun untuk keperluan sekolah, wayang semacam ini dirasakan kurang efektif, karena untuk memainkan boneka ini diperlukan ruangan gelap/tertutup. lagi pula diperlukan lampu untuk membuat bayang-bayang layar.

\section{b. Manfaat Boneka Jari}

Manfaat boneka jari sebagai media pembelajaran adalah:

1) menimbulkan daya tarik siswa;

2) membangkitkan minat bagi siswa untuk belajar;

3) dapat mengembangkan imajinasi siswa;

4) menambah keaktifan siswa;

5) dan menambah suasana gembira pada siswa dalam kegiatan pembelajaran

\section{c. Cara Sederhana Membuat Boneka Jari}

Berikut adalah alat dan bahan serta cara sederhana membuat boneka jari yang dapat kita praktekkan dengan siswa tentunya. Dengan cara yang sederhana ini, guru tidak akan terlalu sulit membimbing siswa dalam proses pembuatannya. Alat dan bahan yang diperlukan yaitu:

1) Kain flanel baru atau pun sisa;

2) Gunting;

3) Kertas;

4) Bolpoin;

5) Lem fox atau bisa juga lem tembak; dan

6) Bagian-bagian pendukung misalnya, putik bunga, mata mainan. 
Cara membuat:

1) Letakkan jari telunjuk diatas kertas sebagai pola atau jari kita yang mana saja sebagai alat untuk mengukur;

2) Gunting kain flanel tersebut sesuai dengan pola;

3) Jahit kedua pola tersebut dengan menggunakan tusuk festoon (untuk hal ini guru harus benar-benar mengawasi siswa);

4) Contoh kali ini adalah membuat kumbang, kita buat lingkaran lalu gunting membentuk segitiga di ujungnya. Jangan lupa buat bintik-bintik hitam kecil sebagai hiasan;

5) Gabungkan antara kain yang telah dijahit dengan pola yang dibuat dengan mengelemnya;

6) Tambahi hiasan putik-putikan sebagai tanduk si kumbang. Boneka jari pun siap dimainkan. Boneka ini uga bisa digunakan sebagai hiasan pensil

\section{KESIMPULAN}

Media pembelajaran merupakan salah satu strategi yang efektif dalam pembelajaran. Media diorama dan boneka jari adalah salah satu APE (Alat Permainan Edukatif) yang memiliki banyak aspek dalam pengembangannya. Dari permainan ini anak bisa menumbuhkan aspek-aspek kognitif, motorik, serta aspek bahasa anak.

Dengan demikian, boneka jari merupakan bagian dari media pembelajaran yang dapat meningkatkan keaktifan, kreatifitas dan imajinasi siswa. Serta membuat proses pembelajaran menjadi lebih bermakna dan siswa pun merasa lebih bergembira dalam menerima pelajaran. Cara pembuatan yang sederhana pun akan membuat para guru tidak terlalu sulit dalam membimbing siswa dalam proses pembuatannya.

\section{DAFTAR PUSTAKA}

Assolihin. 2014. http://paud-anakbermainbelajar.blogspot.com/2014/01/caramembuat-boneka-jari-sederhana.html.

Haryanto. 2012. http://belajarpsikologi.com/pengertian-media-pembelajaran/.

Izzati, Ika Mazkia. 2013.

http://blog.ub.ac.id/ikamazkiaizzati/2013/06/16/penerapan-media-bonekajari-dalam-menunjang-keterampilan-berbicara-siswa-kelas-vii/.

Wahyuti. 2014. http:/ / wahyuti4tklarasati.blogspot.com/2013/05/mediapembelajaran-boneka-jari-dari.html. 